\title{
Growth Hormone Releasing Hormone and Growth Hormone: Genetic Studies in Familial Growth Hormone Deficiency
}

\author{
ALAN D. ROGOL, ROBERT M. BLIZZARD, THOMAS P. FOLEY, JR., RICHARD FURLANETTO, \\ RICHARD SELDEN, KELLY MAYO, AND MICHAEL O. THORNER
}

\begin{abstract}
Departments of Pediatrics, Pharmacology and Internal Medicine, The University of Virginia, Charlottesville, Virginia; Department of Pediatrics, University of Pittsburgh School of Medicine, Pittsburgh, Pennsylvania; The Children's Hospital of Philadelphia, Philadelphia, Pennsylvania; Department of Molecular Biology, Massachusetts General Hospital, Boston, Massachusetts; and The Salk Institute, San Diego, California
\end{abstract}

\begin{abstract}
Four families with growth hormone (GH) deficiency, either isolated or with other pituitary hormonal deficits are described. Members of each underwent pharmacological testing for GH secretion and infusions of GH releasing hormone (GHRH) to determine the locus of the defect in GH secretion. In addition, we have extracted DNA from white blood cells to characterize the GHRH and GH genes. All members tested had the normal complement of GH and GHRH genes. Four generations of one family with isolated GH deficiency, autosomal dominant were studied. The younger members showed minimal GH responsiveness to a single infusion of GHRH. However, the older members did not respond even after 30 doses of GHRH given intravenously every $3 \mathrm{~h}$. Two members of a family with the autosomal recessive type of isolated $\mathbf{G H}$ deficiency had large GH increases after GHRH infusion. Thus in these families the GH secretory defect lies within the hypothalamus. Members of two families with pituitary deficiency (GH and other tropic hormones) of the autosomal recessive type had variable responses to GHRH and varying amounts of pituitary tissue seen on high resolution CT scans. Although it is not possible to delineate the precise location of the secretory defects in these latter two families, a hypothalamic defect is probable based on the responses to multiple trophic stimuli. Heterogeneity of structure and function exists within and between families with isolated GH deficiency and within and among families with pituitary deficiency. It is from the study of such families in which all members presumably have the same underlying defect that one can more readily decide on a pathogenetic mechanism. (Pediatr Res 19: 489-492, 1985)
\end{abstract}

\section{Abbreviations}

GH, growth hormone

GHRH, GH releasing hormone

IV, intravenous

hGH, human growth hormone

TSH, thyroid-stimulating hormone

LH, luteinizing hormone

FSH, follicle-stimulating hormone

Received November 27, 1984; accepted January 18, 1985

Address for reprints Dr. Alan D. Rogol, Department of Pediatrics, Box 386 , University of Virginia School of Medicine, Charlottesville, VA 22908.

Supported in part by US Public Health Service research grants: general clinica research center Grants RR-847 and RR-84, HD-13197 (MOT), AM 32632 [MOT,

a grant from Hoechst AG (RFS), and the Renziehausen Trust (TPF).]
The classification of familial GH deficiency is descriptive and is based on the inheritance of the appropriate phenotype and lack of response to provocative tests for GH secretion. Phillips (1) has distinguished six distinct groups based on the mode of inheritance and other hormone deficiencies. This classification is summarized below as type and mode of inheritance.

Isolated idiopathic $G H$ deficiency. IA, autosomal recessive with absent $\mathrm{GH}$; IB, autosomal recessive with diminished $\mathrm{GH}$; II, autosomal dominant with diminished $\mathrm{GH}$; III, X-linked dominant with diminished $\mathrm{GH}$.

Pituitary dwarfism ( $h G H, T S H, L H, F S H)$. I, autosomal recessive with diminished $\mathrm{GH}$; II, X-linked with diminished $\mathrm{GH}$.

To locate an identifiable genetic cause(s) of these syndromes, we have extracted DNA from patients' white blood cells to locate the GHRH and GH genes and performed pharmacological GH provocative tests and infusions of GHRH in members of families with $\mathrm{GH}$ deficiency.

\section{FAMILIES STUDIED}

Family 1: isolated GH deficiency type II-autosomal dominant. Members of four generations of this family were studied including two men with isolated growth hormone deficiency who married women within this kindred (Fig. 1). The two older women (II-5 and III-3) received GHRH-40 IV every $3 \mathrm{~h}$ for 30 doses in addition to single GHRH-40 tests. No other anterior pituitary hormonal deficit was present.

Family 2: isolated $G H$ deficiency type IB-autosomal recessive. Two GH-deficient sisters ages 15 (CC) and 24 (TC) were studied. They were considered to have type IB deficiency since they produced small amounts of $\mathrm{GH}$ to provocative stimuli. The younger sibling had previously shown accelerated growth after exogenous GH therapy. The older sibling had not been treated. There was no evidence for other anterior pituitary hormonal deficits. Both parents are of normal adult height.

Family 3: pituitary deficiency type I-autosomal recessive. Three GH-deficient siblings with multiple additional anterior pituitary hormonal deficits were investigated-identical twin sisters $13 \mathrm{yr}$ of age (MO, DO) as proven by extensive blood and human lymphocyte antigen typing, and their 18-yr-old human lymphocyte antigen-identical brother (SO). The trophic hormones that were deficient in each are presented in Table 1.

Prior to testing the patients were euthyroid and cortisol sufficient. The 18-yr-old was gonadotropin deficient. The twin sisters were most likely gonadotropin deficient, but because they were only 13 yr old, one cannot make a conclusive statement regarding their gonadotropin status. 


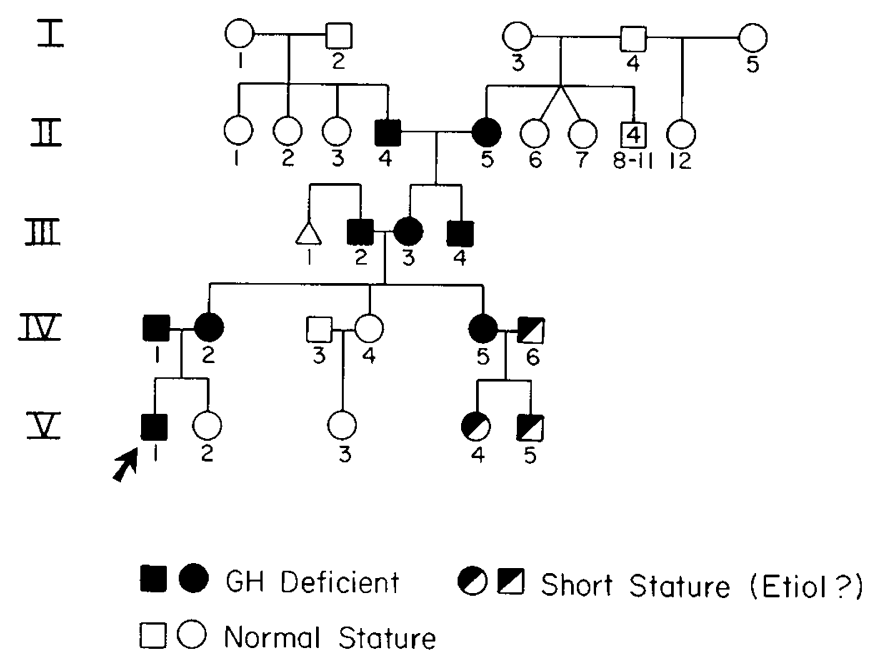

Fig. 1. Kindred for family 1 . The members of the family that were evaluated are the propositus (V-I), IV-2, III-3, and III-5.

Table 1. Deficient trophic hormones

\begin{tabular}{lcccccc}
\hline & \multicolumn{3}{c}{ Family 3 } & \multicolumn{3}{c}{ Family 4 } \\
\hline Member & DO & MO & SO & AC & JC & KC \\
Age (yr) & 13 & 13 & 18 & 5 & 12 & 14 \\
TRH Response & & & & & & \\
TSH & - & + & - & + & - & + \\
Prl & + & + & - & + & - & + \\
GnRH response & & & & & & \\
LH & {$[-]^{*}$} & {$[-]$} & - & {$[-]$} & - & - \\
FSH & {$[-]$} & {$[-]$} & - & {$[-]$} & - & \pm \\
ACTH response & + & + & + & + & - & + \\
\hline
\end{tabular}

* Responses in brackets are indeterminent due to young age.

Family 4: pituitary deficiency type I-autosomal recessive. Three GH-deficient siblings ages $5(\mathrm{AC}), 12(\mathrm{JC})$, and $15(\mathrm{KC})$, with multiple additional anterior pituitary deficits were investigated. Both younger sibs had neonatal hypoglycemia and microphallus. All showed accelerated growth after the administration of exogenous GH. None had received GH therapy for the preceeding $4 \mathrm{wk}$. Prior to testing the patients were euthyroid and cortisol sufficient on appropriate therapy.

\section{METHODS}

The criteria used to define isolated GH deficiency included: 1) short stature at the time of initial presentation (more than $3 \mathrm{SD}$ below mean height for age and sex) except for infants; 2 ) delayed bone age (more than 3 SD below the mean in children while they were still growing); 3) maximum serum $\mathrm{GH}$ levels $(<7 \mathrm{ng} /$ $\mathrm{ml}$ after the administration of 2 or more standard pharmacological stimuli); 4) no evidence for psychosocial deprivation; and 5) subnormal growth velocity that increased into the normal range in those treated with exogenous GH. All had abnormally low basal somatomedin $\mathrm{C}$ concentrations.

Patients with pituitary deficiency fit the criteria outlined above for GH defiency. In addition, they had evidence for other anterior pituitary hormonal deficits.

Approval for the studies was obtained from the Food and Drug Administration and the Human Investigation Committees of the University of Virginia and The Salk Institute. Written informed consent was obtained from the patients and parents. All subjects were admitted to The University of Virginia Clinical Research Center, and eight subjects were studied on the Clinical Research Center at Children's Hospital of Pittsburgh. Subjects were fasted overnight, but were allowed to drink water. At $0600 \mathrm{~h}$ (day 1) an indwelling heparin-lock cannula was placed in a forearm vein for blood withdrawal and for the IV injection of hypothalamic hormones. The subjects remained recumbent during sampling.

$G H$ testing. Growth hormone reserve was tested with arginine $(0.5 \mathrm{~g} / \mathrm{kg} \mathrm{IV}$ over $30 \mathrm{~min}$ ) and L-DOPA (approximately $9 \mathrm{mg} /$ $\mathrm{kg})$ or with insulin-induced hypoglycemia $(0.1 \mathrm{U} / \mathrm{kg}$ IV bolus injection). Members of families 2, 3, and 4 (see below) had previously been tested with multiple pharmacological stimuli to $\mathrm{GH}$ secretion-all GH concentrations had been below $7 \mathrm{ng} / \mathrm{ml}$.

Anterior pituitary stimulation. After three basal blood samples were withdrawn at 15 -min intervals, thyrotropin-releasing hormone $(7 \mu \mathrm{g} / \mathrm{kg})$ and $\mathrm{GnRH}(2 \mu \mathrm{g} / \mathrm{kg})$ were infused as a bolus. Blood samples were withdrawn at 15-min intervals for $2 \mathrm{~h}$ for the determination of $\mathrm{LH}, \mathrm{FSH}, \mathrm{TSH}$ and prolactin.

GHRH-40 infusion tests. GHRH-40 was synthesized and formulated as previously described (2). After three basal blood samples were withdrawn at 15-min intervals, GHRH-40 $(3.3 \mu \mathrm{g} /$ $\mathrm{kg}$ ) was infused as a bolus. However, the three oldest members of family I (II-5, III-3, IV-2) received GHRH-40, $10 \mu \mathrm{g} / \mathrm{kg}$ (see below). Blood samples were withdrawn at 15 -min intervals for 2 $\mathrm{h}$ for the determination of $\mathrm{GH}$.

Two members (II-5 and III-3, Fig. 1) of family I (autosomal dominant isolated growth hormone deficiency type II) received multiple doses of GHRH-40. On the first day, $10 \mu \mathrm{g} / \mathrm{kg}$ of vehicle for GHRH-40 was administered IV at $0800 \mathrm{~h}$ followed by administration of GHRH-40, $10 \mu \mathrm{g} / \mathrm{kg}$ at $0930 \mathrm{~h}$. At $1100 \mathrm{~h}$, GHRH-40, $0.33 \mu \mathrm{g} / \mathrm{kg}$ was given IV bolus and was continued every $3 \mathrm{~h}$ for a total of 30 infusions. On the morning of the $4 \mathrm{th}$ day, both subjects were retested with $10 \mu \mathrm{g} / \mathrm{kg} \mathrm{GHRH}-403 \mathrm{~h}$ after the last dose of $0.33 \mu \mathrm{g} / \mathrm{kg}$. Serum GH concentrations were determined before and for $2 \mathrm{~h}$ after each $0800 \mathrm{~h}$ GHRH administration.

Assays. Serum LH, FSH, TSH, and GH were measured by standard radioimmunoassay techniques as previously described (3). Inter- and intraassay coefficients of variation were less than $10 \%$ in the mid-range of the displacement curves. The modified somatomedin $\mathrm{C}$ assay utilized polystyrene tubes and heparin $(0.5$ $\mathrm{U} / \mathrm{ml}$ ) in the assay buffer (4). The intraassay coefficient of variation was $10 \%$ and the interassay coefficient was $12 \%$.

CT scans. CT scans were performed on the Clinical Research Center at the Children's Hospital of Pittsburgh. Scans were performed at $1.5-\mathrm{mm}$ intervals in the coronal projection before and after IV contrast enhancements.

Preparation of total genomic DNA. Approximately $20 \mathrm{ml}$ of heparinized blood from each subject was treated with ammonium chloride and ammonium bicarbonate to cause erythrolysis as previously described (5). The resulting white cell pellet was incubated in $0.5 \%$ sodium dodecyl sulfate and $0.2 \mathrm{mg} / \mathrm{ml}$ proteinase $\mathrm{K}$ overnight at $55^{\circ} \mathrm{C}$. Following phenol/chloroform/ isoamyl alcohol extraction $(25: 24: 1)$ and ethanol precipitation, the samples were treated with $0.1 \mathrm{mg} / \mathrm{ml}$ ribonuclease $A$ for $1 \mathrm{~h}$ at $37^{\circ} \mathrm{C}$, and the sodium dodecyl sulfate/proteinase $\mathrm{K}$ digestion was repeated. After a final phenol/chloroform/isoamyl alcohol extraction and ethanol precipitation, several hundred $\mu \mathrm{g}$ of total genomic DNA were recovered.

Southern blot analysis. Eight $\mu \mathrm{g}$ of total genomic DNA from each subject was digested to completion with restriction endonuclease Bam HI for human growth gene analysis or Hind III for GHRH gene analysis. The samples were subjected to electrophoresis on $0.9 \%$ agarose gels and transferred to nitrocellulose filters as previously described (6). Prehybridization, hybridization, and washing of filters for the human growth hormone cDNA (7) and the human GHRH cDNA (8) probes were performed essentially as described (9).

\section{RESULTS}

Gene studies. Southern blotting analyses indicate that the genome of each patient contains the five genes of the GH gene family including the GH gene. However, our technique would 
Table 2. Clinical and hormonal data in members of four families with $G H$ deficiency

\begin{tabular}{|c|c|c|c|c|c|c|c|c|c|c|}
\hline \multirow{3}{*}{$\frac{\text { Family }}{1}$} & \multirow{3}{*}{$\frac{\text { Patient }}{\text { WC (II-5) }}$} & \multirow{3}{*}{$\begin{array}{c}\begin{array}{c}\text { Age } \\
(\mathrm{yr})\end{array} \\
81\end{array}$} & \multirow{3}{*}{$\frac{\operatorname{Sex}}{\mathrm{F}}$} & \multirow{3}{*}{$\begin{array}{c}\begin{array}{c}\mathrm{Ht} \\
(\mathrm{cm})\end{array} \\
119\end{array}$} & \multirow{3}{*}{$\frac{\begin{array}{c}\text { hGH Rx } \\
\text { (years) }\end{array}}{\text { None }}$} & \multirow{3}{*}{$\frac{\text { Head CT }}{\mathrm{ND}^{\dagger}}$} & \multirow{3}{*}{$\begin{array}{c}\text { Pharmacologically } \\
\text { stimulated (peak) } \\
\text { GH (ng/ml) } \\
<0.5\end{array}$} & \multicolumn{3}{|c|}{ GHRH-stimulated } \\
\hline & & & & & & & & \multirow{2}{*}{$\begin{array}{c}\begin{array}{c}\mathrm{GH} \text { (peak) } \\
(\mathrm{ng} / \mathrm{ml})\end{array} \\
<0.5\end{array}$} & \multicolumn{2}{|c|}{$\begin{array}{c}\mathrm{SmC}^{*} \\
(\mathrm{U} / \mathrm{ml})\end{array}$} \\
\hline & & & & & & & & & 0.04 & 0.05 \\
\hline & MS (III-3) & 57 & $\mathrm{~F}$ & & None & ND & $<0.5$ & $<0.5$ & 0.01 & 0.03 \\
\hline & DG (IV-2) & 32 & $\mathrm{~F}$ & 135 & None & ND & 1.7 & 1.7 & 0.03 & 0.07 \\
\hline & WG $(V-1)$ & 3 & $\mathrm{M}$ & 82 & None & ND & 1.0 & 3.6 & 0.02 & 0.02 \\
\hline \multirow[t]{2}{*}{2} & $\mathrm{CC}$ & 15 & $\mathrm{~F}$ & 145 & 3 & Normal & 4.1 & 21.4 & 0.61 & 0.51 \\
\hline & $\mathrm{TC}$ & 24 & $\mathrm{~F}$ & 140 & None & Normal & 1.0 & 18.2 & 0.41 & 0.60 \\
\hline \multirow[t]{3}{*}{3} & MO & 13 & $F$ & 150 & None & Normal & 1.2 & ND & 0.22 & \\
\hline & DO & 13 & $F$ & 145 & 2 & Normal & 3.7 & 6.8 & 0.15 & \\
\hline & $\mathrm{SO}$ & 18 & $\mathbf{M}$ & 164 & 12 & $\begin{array}{l}\text { Partially } \\
\text { empty sella }\end{array}$ & 1.4 & 1.0 & 0.08 & \\
\hline \multirow[t]{3}{*}{4} & $\mathrm{AC}$ & 5 & $\mathrm{M}$ & 101 & 3 & $\begin{array}{l}\text { Partially } \\
\text { empty sella }\end{array}$ & 1.1 & 14.9 & 0.04 & 0.07 \\
\hline & $\mathrm{JC}$ & 12 & M & 131 & 11 & No pituitary & 1.3 & 1.9 & 0.07 & 0.03 \\
\hline & $\mathrm{KC}$ & 14 & $\mathrm{~F}$ & 148 & 10 & Small pituitary & 1.3 & 5.7 & 0.36 & 0.34 \\
\hline
\end{tabular}

* Basal $24 \mathrm{~h}$ after GHRH administration.

$\uparrow$ Not done.

not discriminate between the presence of one and the presence of the normal complement of the two hGH-N genes per diploid genome. Similarly, the genome of each patient contains the GHRH gene (data not shown).

Hormonal studies. Family 1 . None of the family members had $\mathrm{GH}$ concentrations above $1.5 \mathrm{ng} / \mathrm{ml}$ (youngest patient) after any pharmacological stimulus. GH concentrations were undetectable $(<0.5 \mathrm{ng} / \mathrm{ml})$ in the older women (II-5 and III-3) in the basal state and after administration of pharmacological stimuli. The $\mathrm{GH}$ concentrations rose minimally after a single dose of GHRH40 in the two younger individuals [to $3.6(\mathrm{IV}-2)$ and $1.7 \mathrm{ng} / \mathrm{ml}$ (V-1)], but did not increase in the older women (II-5 and III-3; all values $<0.5 \mathrm{ng} / \mathrm{ml}$ ). Small but detectable $\mathrm{GH}$ increments (up to $3.5 \mathrm{ng} / \mathrm{ml}$ ) after $\mathrm{GHRH}-40$ were noted in the two GH-deficient men who had married affected women.

Somatomedin $\mathrm{C}$ concentrations were very low and did not rise in any family member after the initial dose of GHRH-40 (Table 2).

The older two women (II-5 and III-3) received multiple IV injections of GHRH-40 at 3-h intervals. Neither the GH nor somatomedin $\mathrm{C}$ concentrations rose after the initial $10 \mu \mathrm{g} / \mathrm{kg}$ dose or after the thirty $0.33 \mu \mathrm{g} / \mathrm{kg}$ doses plus the final $10 \mu \mathrm{g} / \mathrm{kg}$ dose (Table 2).

Family 2. The two young women responded briskly to the single IV injection of GHRH-40 (peak values, 21.4 and $18.2 \mathrm{ng} /$ $\mathrm{ml}$, Table 2). The somatomedin C concentrations did not rise 24 $\mathrm{h}$ after GHRH-40 (Table 2). Low resolution CT scans with and without contrast enhancement were normal.

Family 3. One of the twin girls received GHRH. She had a peak $\mathrm{GH}$ response to $6.8 \mathrm{ng} / \mathrm{ml}$. However, her older brother had a peak response only to $1.1 \mathrm{ng} / \mathrm{ml}$ after the single dose of GHRH40. A summary of the responses of other anterior pituitary hormones are shown in Table 1. There is evidence for more severe anterior pituitary defects in the 18-yr-old male (SO) than in his sisters both from the hormonal data and the $\mathrm{CT}$ scan which showed a partially empty sella.

Family 4. The two boys (AC, JC) had evidence for anterior pituitary deficiency at birth-hypoglycemia and microphallus. Subsequently, both boys and their sister $(\mathrm{KC})$ were noted to have multiple anterior pituitary hormonal deficits (Table 1). Although none had a normal increase in GH concentration after multiple pharmacological stimuli, the youngest boy $(\mathrm{AC})$ demonstrated a brisk response after GHRH-40. The GH response in his older brother (JC) was minimal, but his sister had an intermediate peak response to $5.7 \mathrm{ng} / \mathrm{ml}$. The results of the CT scans of the hypothalamic-pituitary area are shown in Table 2.

\section{DISCUSSION}

Although most patients with $\mathrm{GH}$ deficiency do not have a familial (genetic) incidence, there are at least six single gene disorders that lead to deficiency of GH secretion (1). The members of our four families represent a spectrum in severity of $\mathrm{GH}$ deficiency. The pedigree analysis of family 1 is consistent with autosomal dominant inheritance of the defect in $\mathrm{GH}$ secretion (Fig. 1). A new mutation would have arisen in II-4 or II-5. However, this pedigree could have arisen from autosomal recessive or X-linked dominant inheritance. There is no independent confirmation that II-4 or II-5; III-2, III-3, III-4; IV-1, IV-2, IV-5; and V-1 have the same disorder. The oldest three affected members in three generations had normal pubertal development and all had at least two children. There was no evidence for any other anterior pituitary hormonal deficits and none needed exogenous hormonal therapy. Minimal responses to GHRH-40 were present in the two younger members (IV-2 and V-1), and completely absent in the two older women (II-5 and III-3), even after larger doses $(10 \mu \mathrm{g} / \mathrm{kg})$ or after 30 smaller doses $(0.33 \mu \mathrm{g} /$ $\mathrm{kg}$ ) given every $3 \mathrm{~h}$. Whether these two women had pituitaries that could not respond to GHRH-40 under any circumstances, or whether the "priming" protocol was too short cannot be determined from the present data. However, it is of interest that the youngest member was able to achieve a GH level of $3.6 \mathrm{ng} /$ $\mathrm{ml}$ after a single dose of GHRH-40. He has subsequently grown at a rate of more than $11 \mathrm{~cm} / \mathrm{yr}$ while receiving exogenous $\mathrm{hGH}$. It may be that the somatotrophs of the older women, who had long-standing GRH deficiency, needed a greater priming stimulus to make and secrete GH. Thus, there is some evidence for heterogeneity in the severity of the GH deficiency in these family members. The older individuals are less able to secrete $\mathrm{GH}$ after GHRH-40 stimulation. However, this may represent the normal physiological aging process in whch older individuals are less able to secrete $\mathrm{GH}$ after many different stimuli (10). The increases in GH in the 3-yr-old and his mother, although minimal, suggest a hypothalamic locus of the deficit, although we have not completely excluded a pituitary lesion. The precise location of the deficit in this family might be determined by giving multiple 
doses of GHRH to the youngest member which was not possible at the present time due to his small blood volume.

The second family (isolated growth hormone deficient type IB) has isolated GHRH deficiency based on the lack of adequate $\mathrm{GH}$ responses to pharmacological stimuli to $\mathrm{GH}$ release and the large and brisk response to GHRH-40 injection. The lesion in this type of GH deficiency appears to be in the hypothalamus and could be related to a lack of GHRH or a biologically inactive GHRH.

Members of the third and fourth families (pituitary deficiency type I) have multiple hormonal deficits in addition to a spectrum of severity of GH deficiency both within and between pedigrees.

The heterogeniety of the hormonal deficits is brought into focus by the twin girls in family 3 . They are identical as shown by multiple blood type groups, yet one required GH therapy to attain a height of $145 \mathrm{~cm}$ at $13^{11 / 12} \mathrm{yr}$ (height age $11 \% 12$ ). Her sister, who was not considered to be GH deficient until the present admission, and thus could not receive GHRH-40 under the FDA approved protocol at that time, attained a height of 150 $\mathrm{cm}$ (height age $119 / 12$ ) without GH therapy. Their older brother $(18 \% 12 \mathrm{yr})$ is apparently more severely affected with poorer responses to all anterior pituitary hormonal stimuli and has prepubertal gonadotropin levels and unmeasurable prolactin concentrations.

It is not possible to delineate the precise location of the secretory defects in these patients. It would appear that the lesion is in the pituitary in the most severely affected since he did not respond to multiple trophic stimuli. The hypothalamus is probably the site of the defect in the one twin who received GHRH40 since she responded with $\mathrm{GH}$ release. Both responded to TRH with TSH release. However, it may be that our protocol did not allow enough "priming" of somatotrophs to allow an ultimately responsive pituitary gland to secrete its hormones after GHRH40. The CT scans were normal in the twins and a partially empty sella was found in their brother. The empty sella may result from lack of stimulation of the pituitary by its trophic hormones over many years. Although we favor the hypothalamus as the probable site of the defect, we cannot exclude the possibility of a primary pituitary defect in this particular patient. It is likely that the defect is the same in all the members of this family.

The fourth family is much like the third with a spectrum in severity including both boys who had neonatal hypoglycemia and microphallus. The CT scans also indicate a spectrum of dysfunction ranging from a partially empty sella to virtual absence of the pituitary in JC. In this family one individual responded significantly to GHRH-40 stimulation (serum GH 14.9 $\mathrm{ng} / \mathrm{ml}$ ) and a second responded with a level of $5.7 \mathrm{ng} / \mathrm{ml}$. These results suggest a hypothalamic lesion as the primary site, but as in family 3 , we cannot exclude the possibility of a primary pituitary defect.

The Southern blot analyses indicated that the genome of each patient contained at least one copy of the hGH-N structural gene. These results differ from those of Nishi et al. (11) who identified a Japanese family in which a 7-yr-old boy had evidence for a homozygous large deletion in the hGH-N gene. His initial response to exogenous hGH therapy was as expected for a hypopituitary child; however, he rapidly became resistant to the effects of hGH because of high titer anti-hGH antibodies. In these respects he differs from the families presented herein and the children who continued to respond to GH therapy.

In summary, heterogeneity of structure and function exists within and between families with isolated GH deficiency, and within and among families with pituitary deficiency. If circulating GH levels do not increase after GHRH-40 infusion, one may postulate either a pituitary defect of somatotroph function or that potentially active somatotrophs have not been sufficiently primed to respond. The infusion of GHRH-40 can under certain circumstances define the locus of the defect in GH secretion (families 1 and 2) but there are others, especially those with multiple hormonal deficiencies, in which the precise location cannot be firmly made. It is, however, from the study of such families in which all members presumably have the same underlying deficit that one can more readily decide on a pathogenetic mechanism.

Acknowledgments. The authors thank Mrs. Sandra Jackson and her staff of nurses of the Clinical Research Center for patient care, and Jackie Suttner, R.N., outpatient nurse for the Clinical Research Center at the Children's Hospital of Pittsburgh. Ms. Fotini Beziriannidis is acknowledged for the preparation of the manuscript, and Ms. Kathy Wolfe, E. Elizabeth Taylor, and Rebecca Weaver for their technical assistance. Dr. Joan Atkin assisted with the pedigree analysis.

\section{REFERENCES}

1. Phillips JA 1983 The growth hormone (hGH) gene and human disease. Reprinted from Banbury report 14: recombinant DNA applications to human disease. Cold Spring Laboratory, Cold Spring Harbor, NY

2. Thorner MO, Rivier J, Spiess J, Borges JLC, Vance ML, Bloom SS, Rogol AD, Cronin MJ, Kaiser DL, Evans WS, Webster JD, MacLeod RM, Vale W 1983 Human pancreatic growth hormone releasing factor selectively stimulates growth hormone secretion in man. Lancet 1:24-28

3. Evans WS, Rogol AD, MacLeod RM, Thorner MO 1980 Dopaminergic mechanisms and luteinizing hormone. Secretion: I. Acute administration of the dopamine agonist bromocriptine does not inhibit luteinizing hormone release in hyperprolactinemic women. J Clin Endocrinol Metab 50:103-107

4. Furlanetto RW 1982 Pitfalls in the somatomedin C radioimmunoassay. J Clin Endocrinol Metab 54:1084-1086

5. Kan YW, Dozy AM, Trecartin R, Todd D 1977 Identification of a nondeletion defect in $\alpha$-thalasemmia. N Engl J Med 297:1081-1084

6. Southern EM 1975 Detection of specific sequences among DNA fragments separated by gel electrophoresis. J Mol Biol 98:503-517

7. Martial JA, Hallewell RA, Baxter JD, Goodman HM 1979 Human growth hormone: complementary DNA cloning and expression in bacteria. Science 205:602-607

8. May KE, Vale W, Rivier J, Rosenfeld MG, Evans RM 1983 Expression-cloning and sequence of a cDNA encoding human growth hormone-releasing factor.
Nature 306:86-88

9. Maniatis T, Firtsch EF, Sambrook J 1982 Molecular cloning: a laboratory manual. Cold Spring Harbor Laboratory, Cold Spring Harbor, NY

10. Carlson HE, Gillin JC, Gorden P, Snyder F 1972 Absence of sleep related growth hormone peaks in aged normal subjects and in acromegaly. $J$ Clin Endocrinol Metab 34:1102-1105

11. Nishi Y, Aihara K, Usui T, Phillips JA III, Mallonee RL, Migeon CJ 1984 Isolated growth hormone deficiency type IA in a Japanese family. J Pediatr 104:885-889 